Helgoländer wiss. Meeresunters. 17, 489-495 (1968)

\title{
Biochemical and dynamic circulation of nutrients in the Oslofjord
}

\author{
ERNST FøYN \\ Institute of Marine Biology, University of Oslo, Oslo, Norway
}

\begin{abstract}
KURZFASSUNG: Biochemische und dynamische Zirkulation der Nährstoffe im Oslofjord. Die Rolle der Nährsalze, die mit dem städtischen Abwasser dem Oslofjord zugeführt werden, ist im Hinblick auf ihre Bedeutung für die Eutrophierungsvorgänge untersucht worden. Das Vorkommen verschiedener Verbindungen von Stickstoff und Phosphor, Gesamt-Eisen und Silizium wurde analytisch festgestellt. Andere Nährsalze, die zu den natürlichen Bestandteilen des Meerwassers gehören und deren Konzentration die des Abwassers nur wenig beeinflußt, wurden nicht berücksichtigt. Die Analysen wurden mit Wasserproben, die an verschiedenen Stellen, aus verschiedenen 'Tiefen und zu verschiedenen Jahreszeiten gewonnen worden waren, durchgeführt. Dem quantitativen Gehalt an Eisen und Silizium ist keine entscheidende Rolle bei der Eutrophierung im Jahresablauf zuzuschreiben. Vielmehr bestehen enge Beziehungen zwischen dem Gehalt an Stickstoffverbindungen und dem als Phosphat gebundenen Phosphor zur Phytoplanktonproduktion, so daß wahrscheinlich diese Nährsalze die Pflanzenproduktion im Oslofjord regulieren.
\end{abstract}

\section{INTRODUCTION}

When sewage water is discharged in a river, lake, or fjord, pollution may occur. The degree of such pollution depends (1) on the distribution of particulate and soluble material from the sewage into the water masses of the receiving system, and (2) on the eutrophic conditions which are established through the amount of nutrition compounds in the sewage. During spring and summer, these elements may induce in the recipient a heavy growth of algae which makes the water turbid and discoloured; it further adds to the system organic material in amounts which may be many times higher than the organic material added to the recipient directly by sewage even if discharged as raw sewage. The plant production takes place in the upper layers of the water but as the produced material sinks to the bottom, oxidizing and destructive processes take place. This reduces the oxygen content and even anoxic conditions might occur.

The plant production, and through this, the secondary pollution, is dependent on the amount and the distribution of the nutritional elements released with the sewage. Theoretically, each of the elements, which are required for building up a plant cell, might act as a limiting factor if it is present in a sufficiently low concentration. In a seawater recipient, however, the number of possible limiting constituents is highly reduced, due to the different ions which are brought into the system as components of 
the seawater's salt itself. During our investigations in Oslofjord, this was taken into consideration and as the salinity, even of the surface water, usually exceeds $20 \%$, only the amounts of phosphorous, nitrogen, silicium and iron were found to be of importance as potential limiting factors.

Analytical determinations of nutritional compounds in the Oslofjord have been carried out by the Institute of Marine Biology, University of Oslo, more or less regularly since 1934 . During 1962 to 1965 , the fjord was extensively investigated by the Norwegian Institute of Water Research (NIVA). Water samples from different depths and a number of different stations all over the fjord were analysed monthly. The results have been described in a NIVA report by FøYN (1967).

\section{RESULTS}

Sili i i $\mathrm{m}$ analyses were carried out by NIVA during the period March to December 1965 at all stations and standard depths. Concentrations between 100 and $1,000 \mathrm{mg} / \mathrm{m}^{3}$ were observed. No regular variation with distance from the harbour was found, but usually the values increased as a function of water depth. There was no seasonal variation.

Total iron was analysed by NIVA during the period from October 1964 throughout 1965. Concentrations between 10 and $100 \mathrm{mg} / \mathrm{m}^{3}$ were reported. There were no systematic variations either with the depth, distance from harbour, or with the time of the year.

Nitrogen analyses were carried out by NIVA during the period from March 1964 throughout 1965 at the ordinary stations and depths. For economic and practical reasons only nitrate-nitrogen was determined. The amounts of nitrate-nitrogen vary between 5 and $350 \mathrm{mg} / \mathrm{m}^{3}$; the values increase with water depth and decrease with increasing distance from harbours. In the surface water, great seasonal variations were observed; the values were low during spring and summer, and high during winter. There are, however, some results obtained by The Institute of Marine Biology at station Dp 99 in 1949 and 1950 on nitrate-nitrogen as well as on nitrite- and ammonianitrogen. Figure 1 illustrates the variations of nitrate-, nitrite- and ammonium nitrogen, during 1949 to 1950 . Especially nitrate-nitrogen varied considerably with depth and time.

The rapid increase observed in $75 \mathrm{~m}$ is certainly due to oxidation of organic material containing nitrogen. Later, a reduction in nitrate amounts appears, probably connected to approaching anoxic conditions in this depth. During this period, molecular nitrogen is released. An appreciable amount of ammonium was found in the surface layer; the concentration of this compound seems more constant. The amounts of nitrite are usually too small to be of importance as nutritional compound.

Total phosphorous was determined during 1965, but determinations of orthophosphate were carried out during the whole period 1962 to 1965 . Values from 3 to $700 \mathrm{mg} / \mathrm{m}^{3}$ were found. Orthophosphate increased with increasing depth and decreased with the distance from the harbour. Orthophosphate and total phosphate variation with time at Station $\mathrm{Bnl}$ is demonstrated in Figure 2. 


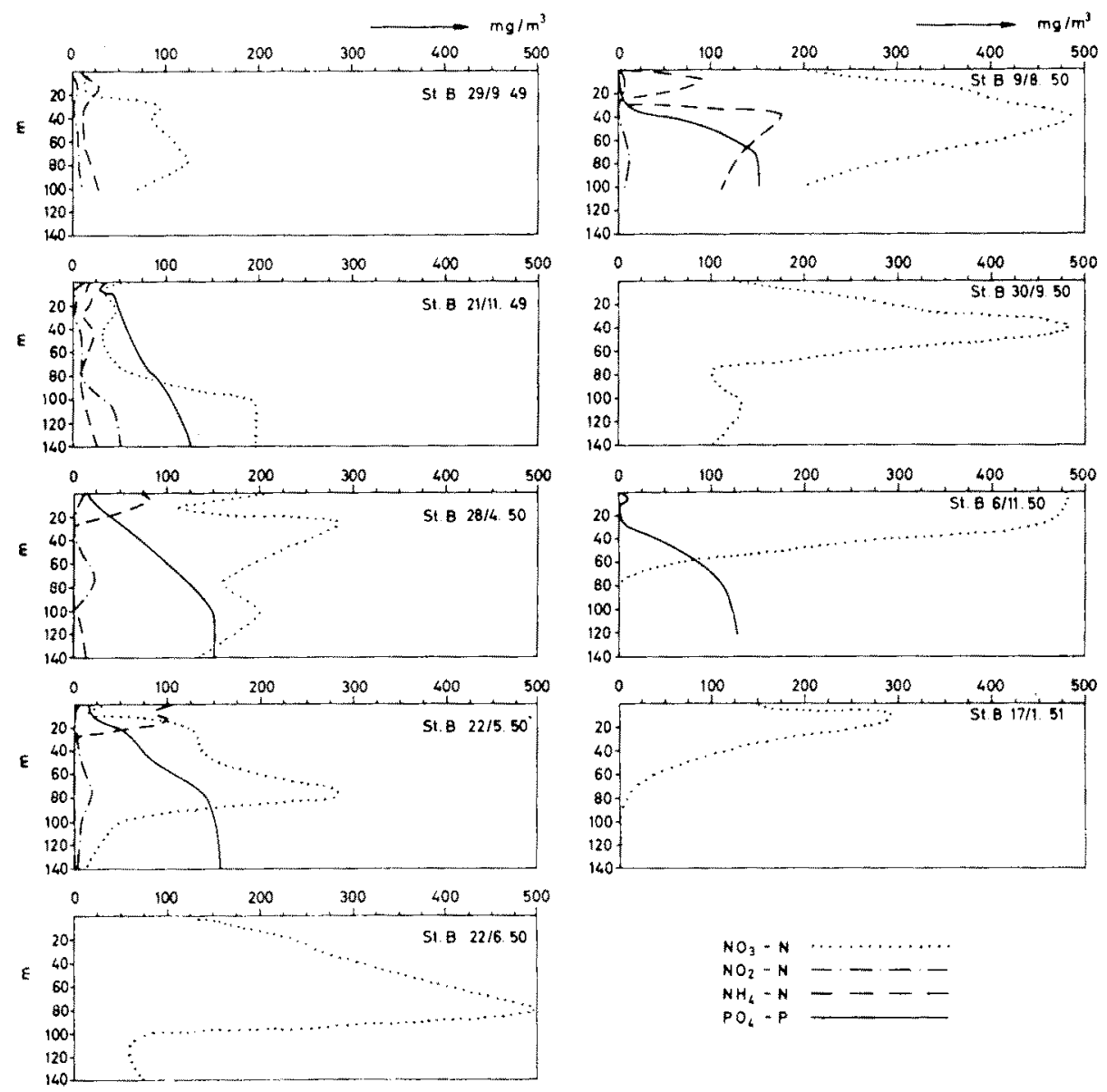

Fig. 1: Nutrition compounds at station Dp 99

The difference between total phosphate and orthophosphate values is the amount of phosphorous which is bound in particulate matter. It is of interest that the amounts of orthophosphate approach, during the summer, the values of total phosphorous, especially in the middle deepwater. In summer, the water in the fjord is more or less stagnant, the distributed organic material is oxidized and phosphorous from the particulate matter liberated as orthophosphate. A simultaneous decrease in oxygen content has always been observed; it is a measure of the intensity of the process.

Figure 3 shows the variations over the year of orthophosphate, given as mean concentration in the 8 upper metres at different stations. High amounts of phosphatephosphorous were found during the winter. The concentrations decrease, however, rapidly during spring, reach a low value in summer, and then increase again in October and November.

Figure 4 gives the concentration of orthophosphate in the upper 8 metres at 


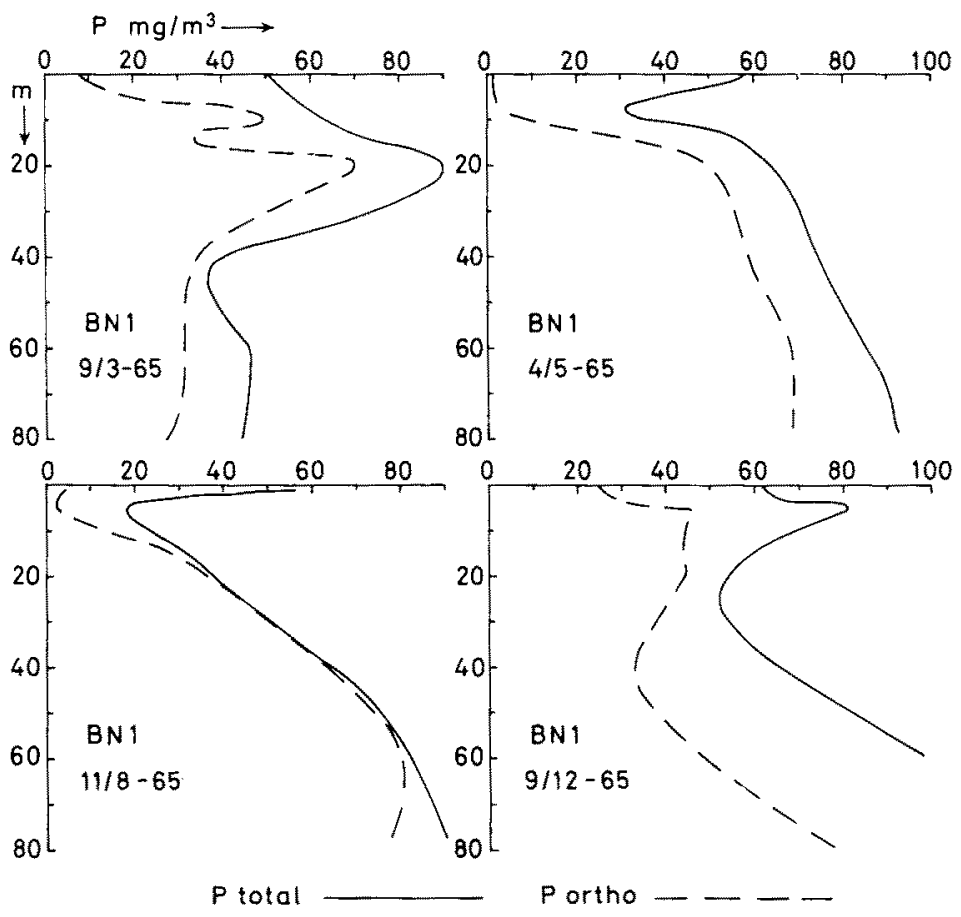

Fig. 2: The variation of orthophosphate and total phophorus in the deep layers through a year represented by four typical dates

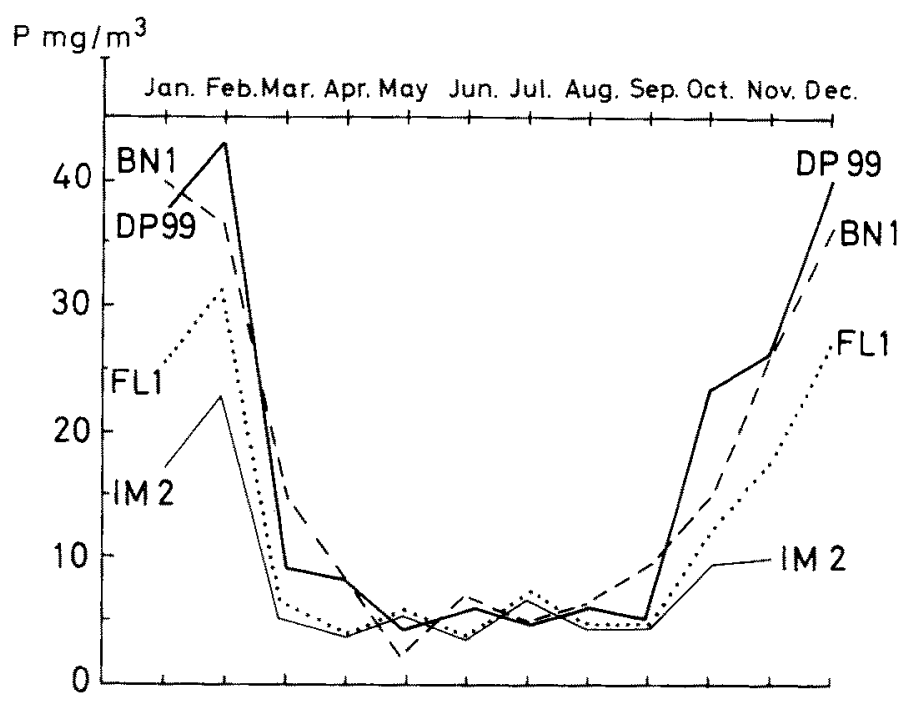

Fig. 3: Annual variations of orthophosphate at four different stations as calculated from the average of 1,4 and $8 \mathrm{~m}$ values (1962 to 1965 ) 


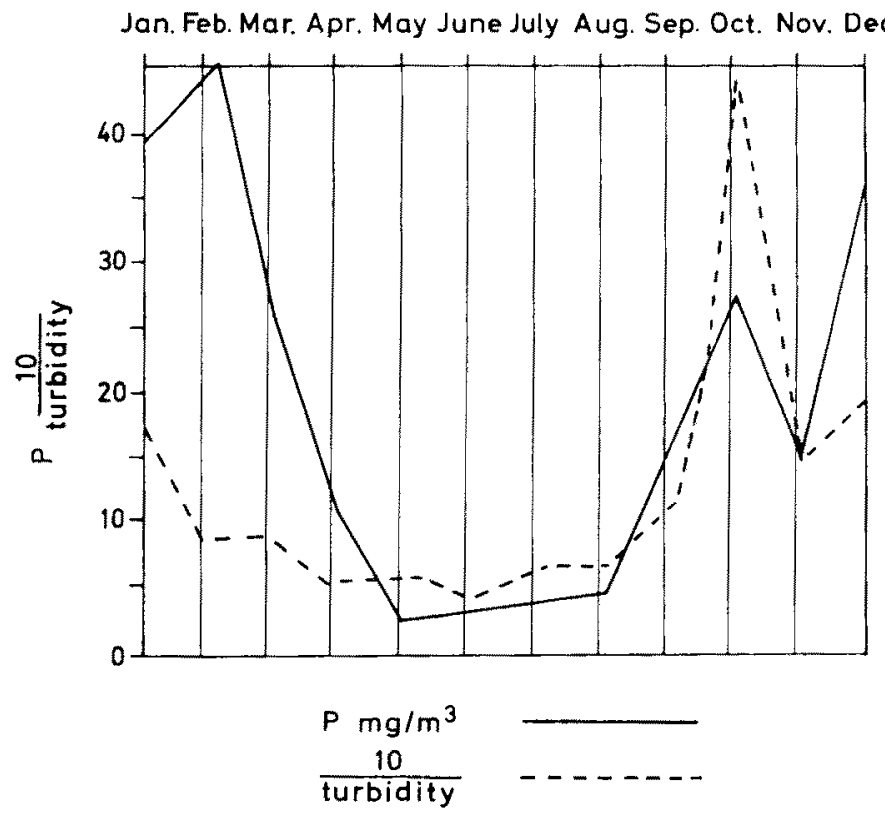

Fig. 4: The relation between orthophosphate and the inverse turbidity. Average of 1,4 and $8 \mathrm{~m}$ values at station $\mathrm{Bn} 1$ (1965). Turbidity in $\mathrm{mg} \mathrm{SiO} 2 / 1$

Station Bnl for different months during 1965, together with a curve based on inverse turbidity values determined at the same station during the same period. The degree of turbidity is an indication of the amount of suspended particles in the water; in our case it may be used as an approximate measure of the concentration of plant cells. The two curves follow each other and demonstrate that a close but negative correlation exists between the concentration of phosphates and the amounts of plant cells in the surface layers of the fjord. The amounts of nutrients released into the fjord through sewage outlets and the river system have been evaluated by JOHANSEN (1967); some pertinent results are presented in Table 1.

Table 1

Calculated total discharge from sewage and from natural drainage to the inner part of the Oslofjord

\begin{tabular}{|lccc|}
\hline $\begin{array}{c}\text { Analytic } \\
\text { component }\end{array}$ & $\begin{array}{c}\text { Ton } \\
\text { per year }\end{array}$ & $\begin{array}{c}\% \text { from } \\
\text { sewage }\end{array}$ & $\begin{array}{c}\% \text { from } \\
\text { rivers }\end{array}$ \\
\hline Total $\mathrm{P}$ & 600 & 79 & 21 \\
$\mathrm{PO}_{4}-\mathrm{P}$ & 350 & 78 & 22 \\
$\mathrm{Total}_{\mathrm{N}}^{\mathrm{NO}}$ & 3500 & 67 & 33 \\
$\mathrm{NO}-\mathrm{N}$ & 580 & 66 & 34 \\
$\mathrm{Fe}$ & 680 & 11 & 89 \\
$\mathrm{BOD}$ & 14600 & 79 & 21 \\
\hline
\end{tabular}




\section{DISCUSSION}

It is obvious that iron as well as silicium, different nitrogen compounds and phosphorous, which are released with the sewage, could be of importance for the plant growth in the Oslofjord. Referring to Table 1 , it is seen, however, that the natural land run-off through the rivers is responsible for about $90 \%$ of the iron discharged into the fjord and it has surely been so during the last hundred years. This, together with the fact that no variations were found on the amounts of this element in any part of the fjord in relation to the production periods of the year, will definitely exclude iron from being of any importance in the eutrophication process or to the secondary pollution of the Oslofjord.

Silicium is probably also of less importance. This element is certainly a nutrient necessary to some sorts of plants, but it is known that if the concentration of silicium decreases, the intake in the organisms is automatically reduced and when no silicium is available other plants will dominate the production. The different nitrogen compounds are, however, of greater importance. The observed variations in the surface layers of the amounts of nitrate-nitrogen showing small concentrations during the productive period of the year and high concentrations during the unproductive period, indicate a close relationship between the amount of nitrate and the plant production of the fjord. When considering nitrogen as a limiting factor, it must, however, be kept in mind that ammonium and even amminoacides may be a source of nitrogen to the plants and these compounds are probably always present to a certain degree in the surface layers. Dealing with phosphorous a close correlation was found between the amounts of orthophosphate and the inverse turbidity values. This indicates that at the present stage of the pollution of the fjord the amount of phosphate-phosphorous which is released with the sewage is probably the factor of the greatest importance. During certain periods of the year concentrations of orthophosphate, very close to zero, were observed at some places in the fjord. Here, therefore, the element is still a limiting factor. If some means should be searched for reducing the secondary pollution of the fjord a reduction of the phosphate released with the sewage seems to be promising. The fact that the concentrations both of nitrogen and phosphorous compounds decrease with the increasing distance from the harbour shows that sewage from the town is the most important source of most plant nutrients to the water in the Oslofjord.

\section{SUMMARY}

1. Concentrations of different compounds of silicium, iron, nitrogen and phosphorous have been determined at different seasons, places and depths in the Oslofjord.

2. The concentrations of various compounds of nitrogen and phosphorous in the fjord depend on the sewage amounts released.

3. Close relations were found between (a) concentrations of nitrate-nitrogen and phosphate-phosphorous in the surface layers and (b) the inverse values of turbidity, a measure of the planktonic plant production in these layers.

4. At the present stage, phosphorous compounds released with the sewage have the greatest importance as factors regulating plant growth. 


\section{LITERATURE CITED}

FøYN, E., 1967. Vurdering av næringssaltenes kjemi. In: Oslofjorden og dens forurensningsproblemer. I. Undersøkelsen 1962-1965. Norwegian Institute of Water Research, Oslo 8, $1-18$.

JOHANSEN, S. S., 1967. Totaltilførsler av forurensningskomponenter via elver, bekker og kloakkledninger til indre Oslofjord. In: Oslofjorden og dens forurensningsproblemer. I. Undersøkelsen 1962-1965. Norwegian Institute of Water Research, Oslo, 11, 1-93. 